\title{
Physico-chemical Characteristics, Functional Properties and Antinutritional Factors of Domestically Processed Sub Himalayan Non- conventional Millet koda (Eleusine coracana)
}

\author{
Shalini Devi* and Rajni Modgil \\ Department of Food Science, Nutrition and Technology, College of Community Science, CSK \\ Himachal Pradesh Agricultural University, Palampur, India \\ *Corresponding author
}

\section{A B S T R A C T}

\begin{tabular}{l} 
Ke y w or d s \\
$\begin{array}{l}\text { Koda (Eleusine } \\
\text { coracana), Physico } \\
\text { chemical } \\
\text { characteristics, } \\
\text { Nutritional } \\
\text { parameters, } \\
\text { Functional } \\
\text { properties, } \\
\text { Antinutritional } \\
\text { factors }\end{array}$ \\
Article Info \\
\hline $\begin{array}{l}\text { Accepted: } \\
\text { 20 October } 2020 \\
\text { Available Online: } \\
\text { 10 November } 2020\end{array}$ \\
\hline
\end{tabular}

\section{Introduction}

The non-conventional crops are also referred by other terms such as underutilized, neglected, alternative or local crops. Some of these crops include the millets such as the finger millet (Eleusine coracona), foxtail millet (Setaria italica), proso or white millet (Panicum miliaceum), barnyard millet (Echinochloa spp.), little millet (Panicum sumatrense), etc which are resistant to adverse climate conditions and can be used to improve the food supply as well as income. Malnutrition is a critical issue contributing to morbidity and mortality among children all over the world. According to the estimates of FAO, after a prolonged decline in world hunger appears to be on the rise again. Resolving malnutrition requires looking back towards the traditional crops because the 
current dependence on a few major crops may result in food scarcity. These indigenous crops can play an important role in combating malnutrition and hidden hunger by preparing more balanced diets.

Non-conventional cereals and millets are easily digestible and rich in micronutrients particularly with regards to calcium and iron, B complex vitamins, essential amino acids phytochemicals and hence are termed as nutri-cereals. Depending on the species, the proximate composition varies. Finger millet (Koda) is considered as a helpful famine crop for the reason that it is stored for lean years (FAO 2012). Koda (Eleusine coracana) is also known by other names such as ragi, mandal, koda, etc. Interesting crop characteristics of koda is the ability to withstand cultivation at altitudes over $2000 \mathrm{~m}$ above sea level, its favorable micronutrient contents (high iron and calcium content), its high drought tolerance, and the long storage time of the grains. Koda plant is utilized as a folk medicine for the treatment of liver disease, measles, pleurisy, pneumonia and small pox.

Traditionally in hill areas of Himachal Pradesh, it is recommended for pregnant and nursing mothers, children and elderly. Farmers in Himachal Pradesh now cultivate koda only for their own consumption or as fodder to the animals and only for preserving the tradition crops. It is grown only in the interior and remote areas of Himachal Pradesh. Koda is losing its importance/popularity in the local food culture although it is rich in nutrient. Its consumption at rural level is also decreasing. Keeping in view the importance of this millet the study was undertaken with the objectives to evaluate physico-chemical characteristics of koda and to assess the effect of processing on its nutritional and functional quality.

\section{Materials and Methods}

Koda (Eleusine coracana) grains were collected from the region of Sirmaur, Himachal Pradesh, India which were cleaned manually for removing adhering dirt, dust and foreign particles.

To study the physical characteristics the grains were kept in as airtight food grade polyethylene terephthalate container at low temperature $\left(4-\quad 7^{\circ} \mathrm{C}\right)$ until further examination. To study the chemical characteristics, functional properties and antinutritional factors samples were divided into four lots. One lot was kept as such other three were popped, pressure cooked and germinated.

\section{Popping}

Koda grains were soaked in water for $10 \mathrm{~min}$ and then dried on filter paper. The soaked seeds were kept aside for $10 \mathrm{~min}$ to gain optimum moisture content. Popping was carried out by dropping the seeds in a preheated cauldron and moving with the help of molded cloth until the seeds were popped.

\section{Pressure cooking}

Pressure cooking of koda grains was carried out in pressure cooker for $30 \mathrm{~min}$ by adding water double the amount of millet grains. The grains were dried in hot air oven at $55^{\circ} \mathrm{C}$ for $12 \mathrm{hrs}$.

\section{Germination}

Koda grains were steeped in potable tap water for $12 \mathrm{hrs}$ and the grain water ratio (1:3) was such as to dip the seeds completely. The containers were then covered with filter paper sheets. After $12 \mathrm{hrs}$ the water was drained off and the grains were ready for subsequent germination. The soaked seeds were kept in 
trays lined with wet sand beds of $2 \mathrm{~cm}$ thickness, covered with filter paper sheets and allowed to germinate. Grains took $48 \mathrm{hrs}$ for germination (about $1-1.5 \mathrm{~cm}$ long). Regular sprinkling of water at equal interval was carried out to keep grains moist. The grains were dried in hot air oven at $55^{\circ} \mathrm{C}$ for $12 \mathrm{hrs}$ in trays.

The raw, popped, pressure cooked and germinated samples were separately ground to a fine powder with the help of mixer grinder, dried to a desired moisture content (AOAC 2010) and stored in airtight food grade polyethylene terephthalate containers at 4$7^{\circ} \mathrm{C}$ until further analysis.

\section{Physical characteristics and proximate composition}

The size of 10 grains in triplicate was measured in terms of length (L) and width (W) with the help of Vernier Caliper. Proximate constituent's viz. Moisture, ash, crude fat and crude fiber contents in the samples were determined by standard methods of AOAC (2010). Nitrogen was analyzed by Micro-kjeldhal (AOAC 2010) and was multiplied by factor 5.83 for converting it into crude protein.

\section{Nutritional parameters and functional properties}

Energy in the samples was determined by chromic oxide method of O'Shea and Maguire (1962). The sugars and were estimated by standard method of AOAC (2010). Non Protein Nitrogen (NPN) in samples was determined as per the method used by Modgil (2016). True protein was calculated by the following formula: Crude protein nitrogen - Non protein nitrogen)*5.83. Water and oil absorption capacity was determined by the method of Adebowale et al., (2005). Swelling power and percent solubility was estimated by the method of Schoch (1964).

\section{Dietary fibre constituents}

Dietary insoluble fiber constituents include neutral detergent fiber (NDF), acid detergent fiber (ADF), lignins, cellulose and hemicellulose. NDF and ADF was estimated by the method of Van Soest and Wine (1967). Lignin content was estimated by the method of Van Soest and Robertson (1985). Hemicellulose was calculated by the formula NDF - ADF. Cellulose was calculated by using following formula ADF - Lignin.

\section{Determination of total phenols, phytic acid,} phytate phosphorus, oxalates and saponins

Total phenols in the samples were determined by the method given by Makkar et al., (1993). Phytic acid was estimated in the samples by the method of Haugh and Lantzch (1983). Phytate phosphorus was calculated by

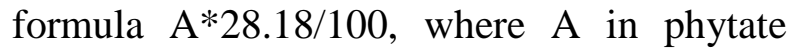
content. Non- phytate phosphorus was calculated as the difference between the total phosphorus and phytate phosphorus. Oxalate was determined by the method of Day and Underwood (1986). Saponin was estimated by the method of Obadoni and Ochuko (2001).

\section{Statistical analyses}

The experiments were carried out in triplicate and the data so obtained were subjected to analysis of variance (ANOVA) using statistical package OPSTAT (Sheoran et al., 1998). The obtained data were interpreted at 5 per cent level of significance $(p \leq 0.05)$.

\section{Results and Discussion}

Effect of domestic processing on the size of Koda (Eleusine coracana)

A significant $(\mathrm{p} \leq 0.05)$ difference was observed in the length of koda seeds when 
different processing techniques were applied (Table 1). The average length of raw koda seed was $1.43 \pm 0.90 \mathrm{~mm}$ which increased to $2.17 \pm 0.05 \mathrm{~mm}(51.75 \%)$ in pressured cooked grain samples, followed by popping $2.04 \pm 0.05 \mathrm{~mm}(49.65 \%)$ and minimum increase i.e. $8.39 \%(1.55 \pm 0.05 \mathrm{~mm})$ was noted in the germinated seeds. The increase in length during steaming and germination might be due to absorption of more water by seeds. During popping the increase might be due to expansion of seed. Pressure cooking resulted in the significant $(\mathrm{p} \leq 0.05)$ increase in the width $(1.84 \pm 0.05 \mathrm{~mm})$ of koda seeds when compared with popped $(1.75 \pm 0.04 \mathrm{~mm})$ and raw koda $(1.40 \pm 0.05 \mathrm{~mm})$ seeds. Germination $(1.57 \pm 0.04 \mathrm{~mm})$ resulted in less increase in width as compared to popping and pressure cooking. Increase in width during steaming might have been due to absorption of more water and swelling of seeds, whereas during popping width increased due to puffing of seeds due to starch and moisture present in seeds.

\section{Effect of domestic processing on the proximate composition of Koda (Eleusine coracana)}

Data in Table 1 reveals the effect of processing on proximate composition of koda. As is clear from the data that a significant $(p \leq 0.05)$ difference was observed in moisture and fibre content of untreated and popped koda. Popping resulted in a significant decrease in moisture i.e. $9.55 \pm 0.41$ to $1.27 \pm$ 0.12 whereas crude ash and fibre increased from $2.77 \pm 0.05$ to $3.21 \pm 0.03$ and $4.67 \pm 0.19$ to $6.56 \pm 0.48$ per cent, respectively. The increase in crude fibre content might have been due to moisture losses and due to increase in insoluble and non-digestible material produced during heat treatment. Malik et al., (2002) also reported increase in crude fibre content in roasted samples of pearl millet due to the formation of non-digestible complexes. Untreated koda contained $9.08 \pm$ 0.24 per cent crude protein which non significantly $(\mathrm{p} \leq 0.05)$ decreased to $8.54 \pm$ 0.24 per cent with popping. The decrease in protein content during popping might have been due to denaturation of protein due by thermal treatment. Protein content decreased non - significantly $(\mathrm{p} \leq 0.05)$ during pressure cooking from $9.08 \pm 0.24$ to $8.41 \pm 0.16$ per cent whereas, a significant $(\mathrm{p} \leq 0.05)$ increase in moisture content was observed i.e. $9.55 \pm$ 0.41 to $10.86 \pm 0.70$ per cent. Pressure cooking resulted in a significant $(\mathrm{p} \leq 0.05)$ decrease in fibre content i.e. $4.67 \pm 0.19$ to $4.04 \pm 0.24$ per cent. The increase in moisture content might have been due to absorption of water during cooking. Germination resulted in significant $(\mathrm{p} \leq 0.05)$ increase in the moisture, ash, fibre and protein content of koda i.e. $9.55 \pm 0.41$ to $10.39 \pm 0.15 ; 2.77 \pm 0.05$ to 3.51 $\pm 0.21 ; 4.67 \pm 0.19$ to $5.96 \pm 0.27$ and $9.08 \pm$ 0.24 to $10.12 \pm 0.54$ per cent, respectively. The increase in protein and fibre content during germination might have been due to synthesis of new proteins fibre complexes to meet the need of growing seedling and to support the growth of roots and shootlets. Akubor and Obiegbuna (1999) also found increase in crude protein and fibre content during germination of millet. Moreover, germination also resulted in an increased absorption rate of minerals and trace elements from sprouts and reduction in anti nutrients that binds them. Ash content might have increased due to increased mineral content. Modgil et al., (2016) also reported similar results during germination of fenugreek seeds.

The highest carbohydrate content was found in popped koda i.e. $79.52 \pm 0.18$ per cent followed by pressure cooked (72.69 \pm 0.93 $\%)$, raw $(72.52 \pm 0.25 \%)$ and germinated $(68.94 \pm 0.97 \%)$. Popping resulted in increase in carbohydrate content which might have been due to the reason that during popping moisture losses were there, nutrients 
become more concentrated. Popping also leads to hardness of cell structures and thus increasing carbohydrates, whereas during sprouting there is decrease in total carbohydrate content of koda which might have been due to hydrolysis of starch content during germination which is a reserve form of carbohydrate in plants which is utilized as an energy source during germination thus reducing its content. Modgil et al., (2016) also reported similar results during germination of fenugreek seeds.

\section{Calorific value and sugars}

A glance at Table 1 shows that koda yielded $281.33 \pm 1.65 \mathrm{Kcal} / 100 \mathrm{~g}$. In an earlier report Nazni and Bhuvaneswari (2015) reported higher values of energy content in finger millet (Eleusine coracana L) i.e. $370.3 \pm$ 10.90 Kcal which could be due to the difference in cultivars and agro-climatic conditions. Whereas, similar value have been reported by Thippeswamy et al., (2016) for calorific value in native finger millet cultivar. Maximum value of energy content was present in popped koda i.e. $299.27 \pm 4.66$ Kcal minimum was present in germinated koda $(277.86 \pm 4.64 \mathrm{Kcal})$. Pressure cooking and germination resulted in decrease in energy content. Cooked koda contained $279.43 \pm 4.70 \mathrm{Kcal}$. Increase in energy content might be due to decrease in moisture content during popping. The decrease in energy value during germination might have been due to the reason that in germination stage hydrolysis of starch and lipolysis of fat take place so carbohydrate content is decreased as a result calorific value is affected. Similar results were reported by Modgil et al., (2016) in fenugreek seeds. Total sugars, reducing sugars and nonreducing sugars content in koda was $2.16 \pm$ $0.4,1.51 \pm 0.07$ and $0.65 \pm 0.09$ per cent, respectively. Katake et al., (2016) reported the reducing, non-reducing, total sugars of finger millet genotypes ranged between 0.23 $0.42, \quad 0.65-0.89$ and 1.02 - $1.20 \mathrm{~g}$, respectively. A significant $(\mathrm{p} \leq 0.05)$ difference in reducing sugar content was observed when popped $(0.79 \pm 0.02 \%)$, pressure cooked $(0.77 \pm 0.03 \%)$ and germinated $(0.87 \pm 0.03$ $\%)$ sample was compared with untreated $k o d a$. The increase in reducing sugar content during germination might have been due to the reason that carbohydrates consists primarily of low molecular weight oligosaccharides particularly sucrose, raffinose and stachyose. Total sugars mostly representing the non-reducing sugars are acted upon by $\alpha$-galactosidases which get activated during germination. So, breakdown of non-reducing sugars results in increased formation of reducing sugars. However, increase of reducing sugar content during popping and pressure cooking might have been due to the biochemical changes taking place during heating as a result complex carbohydrates are broken down in to simple sugars. Akintosotu and Akinyele (1991) reported that germination increased starch digestibility and sucrose, fructose, glucose and galactose contents while oligosaccharides content decreased.

A glance at Table 1 reveals that the non reducing sugar content of untreated, popped, pressure cooked and germinated koda was $1.51 \pm 0.07,1.45 \pm 0.03,1.49 \pm 0.05$ and 1.43 \pm 0.09 per cent, respectively. The non reducing sugar content decreased significantly $(\mathrm{p} \leq 0.05)$ during processing. The decrease in non-reducing sugar content of popped koda might have been due to bio-chemical changes taking place during heating as a result complex carbohydrates are broken down in to simple sugars. The decrease in non-reducing sugar content of germination might have been due to the result of seed respiration and hydrolysis of starch which is converted in to simpler sugars like glucose and maltose which are reducing sugars. The maximum 
total sugar was present in germinated koda $(2.31 \pm 0.13 \%)$ and minimum in untreated koda $(2.16 \pm 0.04 \%)$. A significant $(\mathrm{p} \leq 0.05)$ difference was observed in total sugars when untreated koda was compared with germinated koda. The increase in total sugar content on germination can be attributed to increased activity of $\alpha$-amylase and rapid depletion of starch which may probably account for the increase of total sugar during germination. Whereas, roasting and pressure cooking resulted in an increase in total sugars content might have been due to the biochemical changes taking place during heating as a result complex carbohydrate are broken in to simple sugars.

\section{Non Protein Nitrogen (NPN), true protein}

Data in Table 1 shows the non protein nitrogen, true protein and amino acids composition of koda. It is evident from data that the NPN and true protein content of koda was $0.75 \pm 0.16$ and $4.60 \pm 0.47$ per cent, respectively. Popping $(0.62 \pm 0.10)$, pressure cooking $(0.51 \pm 0.21)$ and germination $(0.42 \pm$ $0.14)$ resulted in non - significant $(\mathrm{p} \leq 0.05)$ decrease in NPN whereas, true protein content increased during processing. Popped, pressure cooked and germinated koda contained $4.95 \pm$ $0.58,5.41 \pm 1.25$ and $5.96 \pm 0.91$ per cent true protein content, respectively. The decrease in NPN content during pressure cooking might have been due to the reason that during heat treatment degradation of enzymes may occur which results in an increase in NPN content whereas decrease in NPN content on germination and steaming might have been due to leaching out of low molecular weight nitrogen compounds in water during these treatments and increase in true protein content due to activation of certain enzymes which lead to protein synthesis.

\section{Table.1 Effect of domestic processing on physico-chemical characteristics of koda (Eleusine coracana)}

\begin{tabular}{|l|c|c|c|c|c|}
\hline Parameters & Raw & Popped & $\begin{array}{c}\text { Pressure } \\
\text { cooked }\end{array}$ & Germinated & $\begin{array}{c}\text { CD } \\
(\mathbf{p} \leq \mathbf{0 . 0 5})\end{array}$ \\
\hline Length (mm) & $1.43 \pm 0.90$ & $2.04 \pm 0.05$ & $2.17 \pm 0.05$ & $1.55 \pm 0.05$ & 0.06 \\
\hline Width (mm) & $1.40 \pm 0.05$ & $1.75 \pm 0.04$ & $1.84 \pm 0.05$ & $1.57 \pm 0.04$ & 0.06 \\
\hline Moisture (\%) & $9.55 \pm 0.15$ & $1.27 \pm 0.12$ & $10.86 \pm 0.70$ & $10.39 \pm 0.15$ & 0.71 \\
\hline Crude Ash (\%) & $2.77 \pm 0.05$ & $3.21 \pm 0.03$ & $2.62 \pm 0.07$ & $3.51 \pm 0.21$ & 0.22 \\
\hline Crude Fat (\%) & $1.39 \pm 0.23$ & $1.22 \pm 0.13$ & $1.38 \pm 0.02$ & $1.08 \pm 0.51$ & NS \\
\hline Crude Protein (\%) & $9.08 \pm 0.24$ & $8.54 \pm 0.24$ & $8.41 \pm 0.16$ & $10.12 \pm 0.54$ & 0.62 \\
\hline Crude Fibre (\%) & $4.67 \pm 0.20$ & $6.56 \pm 0.48$ & $4.04 \pm 0.24$ & $5.96 \pm 0.27$ & 0.6 \\
\hline Total Carbohydrate (\%) & $72.52 \pm 0.25$ & $79.20 \pm 0.18$ & $72.69 \pm 0.93$ & $68.94 \pm 0.97$ & 1.32 \\
\hline Energy (Kcal/100g) & $281.33 \pm 4.65$ & $299.27 \pm 4.66$ & $279.43 \pm 4.70$ & $277.86 \pm 4.64$ & 7.47 \\
\hline Reducing Sugars (\%) & $0.65 \pm 0.09$ & $0.79 \pm 0.02$ & $0.77 \pm 0.03$ & $0.87 \pm 0.03$ & 0.1 \\
\hline Non-reducing sugars (\%) & $1.51 \pm 0.07$ & $1.45 \pm 0.03$ & $1.49 \pm 0.05$ & $1.43 \pm 0.09$ & 0.05 \\
\hline Total Sugars (\%) $(\%)$ & $2.16 \pm 0.04$ & $2.24 \pm 0.05$ & $2.27 \pm 0.12$ & $2.31 \pm 0.13$ & 0.14 \\
\hline NPN (\%) & $0.75 \pm 0.16$ & $0.62 \pm 0.10$ & $0.51 \pm 0.21$ & $0.42 \pm 0.14$ & NS \\
\hline True Protein (\%) & $4.60 \pm 0.47$ & $4.95 \pm 0.58$ & $5.41 \pm 1.25$ & $5.96 \pm 0.91$ & NS \\
\hline
\end{tabular}


Table.2 Effect of domestic processing on functional properties of koda (Eleusine coracana)

\begin{tabular}{|l|c|c|c|c|c|}
\hline Parameters & Raw & Popped & $\begin{array}{c}\text { Pressure } \\
\text { cooked }\end{array}$ & Germinated & $\begin{array}{c}\text { CD } \\
(\mathbf{P} \leq \mathbf{0 . 0 5})\end{array}$ \\
\hline $\begin{array}{l}\text { Water absorption } \\
\text { capacity (ml/g) }\end{array}$ & $1.61 \pm 0.15$ & $2.54 \pm 0.19$ & $2.75 \pm 0.03$ & $2.57 \pm 0.38$ & 0.43 \\
\hline $\begin{array}{l}\text { Oil absorption } \\
\text { capacity (ml/g) }\end{array}$ & $1.17 \pm 0.10$ & $2.14 \pm 0.20$ & $1.61 \pm 0.16$ & $0.87 \pm 0.21$ & 0.33 \\
\hline Swelling power (g/g) & $5.28 \pm 0.39$ & $10.45 \pm 0.78$ & $11.72 \pm 0.67$ & $4.24 \pm 0.09$ & 3.30 \\
\hline Solubility (\%) & $1.40 \pm 0.56$ & $5.07 \pm 1.04$ & $4.90 \pm 0.95$ & $0.60 \pm 0.26$ & 1.96 \\
\hline
\end{tabular}

Table.3 Effect of processing on Dietary fibre constituents of koda (Eleusine coracana)

\begin{tabular}{|l|c|c|c|c|c|}
\hline Parameters & Raw & Popping & $\begin{array}{c}\text { Pressure } \\
\text { cooked }\end{array}$ & Germination & $\begin{array}{c}\text { CD } \\
(\mathbf{p} \leq \mathbf{0 . 0 5})\end{array}$ \\
\hline NDF (\%) & $28.93 \pm 0.90$ & $34.47 \pm 0.76$ & $29.60 \pm 0.89$ & $37.20 \pm 1.11$ & 3.09 \\
\hline ADF (\%) & $14.27 \pm 1.01$ & $16.47 \pm 0.12$ & $16.00 \pm 0.40$ & $12.67 \pm 0.61$ & 1.19 \\
\hline Cellulose (\%) & $7.47 \pm 0.94$ & $8.87 \pm 0.12$ & $9.60 \pm 0.53$ & $7.20 \pm 0.72$ & 1.25 \\
\hline Hemicellulose (\%) & $14.67 \pm 1.79$ & $18.00 \pm 2.80$ & $13.60 \pm 0.53$ & $24.53 \pm 1.53$ & 3.53 \\
\hline Lignin (\%) & $6.80 \pm 0.20$ & $7.60 \pm 0.20$ & $6.40 \pm 0.20$ & $5.47 \pm 0.31$ & 0.44 \\
\hline
\end{tabular}

Table.4 Effect of domestic processing on total phenols content and antinutritional factors of koda (Eleusine coracana)

\begin{tabular}{|l|c|c|c|c|c|}
\hline Parameters & Raw & Popping & $\begin{array}{c}\text { Pressure } \\
\text { cooked }\end{array}$ & Germination & $\begin{array}{c}\text { CD } \\
(\mathbf{P} \leq \mathbf{0 . 0 5})\end{array}$ \\
\hline $\begin{array}{l}\text { Total Phenols } \\
\text { (mg TAE/100g) }\end{array}$ & $27.94 \pm 1.46$ & $63.58 \pm 5.18$ & $17.58 \pm 1.21$ & $34.04 \pm 0.19$ & 5.28 \\
\hline Saponin (g/100g) & $5.67 \pm 0.31$ & $5.53 \pm 0.24$ & $4.76 \pm 0.58$ & $5.36 \pm 0.04$ & 0.89 \\
\hline $\begin{array}{l}\text { Phytic acid } \\
\text { (mg/100g) }\end{array}$ & $89.65 \pm 0.50$ & $84.44 \pm 0.41$ & $86.25 \pm 0.23$ & $86.70 \pm 0.21$ & 2.67 \\
\hline $\begin{array}{l}\text { Oxalates } \\
\text { (mg/100g) }\end{array}$ & $1.80 \pm 0.18$ & $1.60 \pm 0.07$ & $0.51 \pm 0.10$ & $1.74 \pm 0.13$ & 0.24 \\
\hline
\end{tabular}

Effect of domestic processing on functional properties of Koda (Eleusine coracana)

As clear from the data (Table 2), the water absorption capacity of koda flour was $1.61 \pm$ $0.15 \mathrm{ml} / \mathrm{g}$. High WAC of flour suggests that the flour can be used for formulating foods such as sausages and bakery products. Although the water absorption capacity increased in popping $(2.54 \pm 0.19 \mathrm{ml} / \mathrm{g})$, pressure cooking $(2.75 \pm 0.03 \mathrm{ml} / \mathrm{g})$ and germination $(2.57 \pm 0.38 \mathrm{ml} / \mathrm{g})$, the difference among treatments was non - significant $(\mathrm{p} \leq 0.05)$. This slight increase in WAC might have been due to the change in structure of starch and proteins. The oil absorption capacity of flour is equally important as it improves the mouth feel and retains the flavor. As evident from data, the oil absorption capacity of koda flour was $1.17 \pm$ $0.10 \mathrm{ml} / \mathrm{g}$. Significantly $(\mathrm{p} \leq 0.05)$ higher oil absorption capacity was noted in the seeds 
after popping $(2.14 \pm 0.20 \mathrm{ml} / \mathrm{g})$. Pressure cooking $(1.61 \pm 0.16 \mathrm{ml} / \mathrm{g})$ and germination $(0.87 \pm 0.21 \mathrm{ml} / \mathrm{g})$ resulted in a decrease in oil absorption capacity. The increase in oil absorption capacity after popping might have been due to change in structure and chemical composition of seeds.

It is clear from the table that swelling power and solubility of koda flour were observed as $5.28 \pm 5.28 \mathrm{~g} / \mathrm{g}$ and 1.40 per cent. Processing techniques like popping and pressure cooking resulted in increase swelling power, whereas germination resulted in decrease in swelling power. But a non - significant $(\mathrm{p} \leq 0.05)$ difference was observed in swelling power of popped $(10.45 \pm 0.78 \mathrm{~g} / \mathrm{g})$ and pressure cooked $(11.72 \pm 0.67 \mathrm{~g} / \mathrm{g}) \quad k o d a$ when compared with each other but they differed significantly $(\mathrm{p} \leq 0.05)$ from germinated seeds $(4.24 \pm 0.09 \mathrm{~g} / \mathrm{g})$. Difference in swelling power during germination is because starch has been utilized for the production of new seedlings, whereas during popping and steaming starch structure has been modified. Untreated koda had $1.40 \pm 0.56$ per cent solubility which was significantly $(\mathrm{p} \leq 0.05)$ lower when compared with popped (5.07 \pm 1.04 per cent) and pressure cooked seeds (4.90 \pm 0.95 per cent) there was a non significant $(\mathrm{p} \leq 0.05)$ difference in the solubility of popped and cooked seeds when compared with each other. The increase in the solubility of the popped seeds might have been due to the conversion of starch to dextrin during popping and during cooking increase in the solubility might have been due to the hydrolysis of starch.

\section{Dietary fibre constituents}

Data pertaining to the effect of popping, pressure cooking and germination on dietary fibre constituents of koda is given in Table 3. The NDF, ADF, cellulose, hemicellulose and lignin content of raw koda was found to be
$28.93 \pm 0.90,14.27 \pm 1.01,7.47 \pm 0.94,14.67$ \pm 1.79 and $6.80 \pm 0.20$ per cent, respectively. However, these dietary fibre constituents significantly $(\mathrm{p} \leq 0.05)$ increased with popping. The NDF, ADF, cellulose, hemicellulose and lignin content of popped koda was found to be $34.47 \pm 0.76,16.47 \pm 0.12,8.87 \pm 0.12$, $18.00 \pm 2.80$ and $7.60 \pm 0.20$ per cent Pressure cooking resulted in significant $(\mathrm{p} \leq 0.05)$ increase in ADF $(16.00 \pm 0.40 \%)$ and cellulose $(9.60 \pm 0.53 \%)$ content whereas lignin content $(6.40 \pm 0.20 \%)$ decreased non - significantly $(\mathrm{p} \leq 0.05)$ with cooking. As is clear from the data that germination resulted in significant $(p \leq 0.05)$ increase in NDF and hemicelluloses content whereas ADF, cellulose, hemicellulose and lignin content decreased during germination. Germinated koda contained $37.20 \pm 1.11$ per cent NDF, $12.67 \pm 0.61$ per cent ADF, $7.20 \pm 0.72$ per cent cellulose, $24.53 \pm 1.53$ per cent hemicelluloses and $5.47 \pm 0.31$ per cent lignin content.

\section{Total phenols}

As evident from the Table 4, total phenol content found in koda was $27.94 \pm 1.46 \mathrm{mg}$ TAE/100g. Dharmaraj and Malleshi (2011) reported polyphenols in finger millet of native millet as 1.80 per cent. The total phenol content was significantly higher in popped koda $(63.58 \pm 5.18 \mathrm{mg}$ TAE/100g) compared to raw $(27.94 \pm 1.46 \mathrm{mg} \mathrm{TAE} / 100 \mathrm{~g})$, pressure cooked (17.58 mg TAE/100g) and germinated koda (34.04 $\pm 0.19 \mathrm{mg}$ TAE/100g). The decrease in total phenol content during pressure cooking might have been due to alteration in the chemical structure. However the increase in total phenol content during germination might have been due to many metabolic activities and changes such as an increase in the activity of the endogenous hydrolytic enzymes may occur in the seeds during germination process. 
Effect of domestic processing on Antinutritional characteristics of Koda (Eleusine coracana)

A glance at Table 4 shows that maximum phytic acid and oxalate content was found in untreated koda i.e. $89.65 \pm 0.50$ and $1.80 \pm 0.18 \mathrm{mg} / 100 \mathrm{~g}$, respectively which decrease to $84.44 \pm 0.41$ and $1.60 \pm 0.07 \mathrm{mg} / 100 \mathrm{~g} ; 86.25 \pm 0.23$ and $0.51 \pm$ 0.10 ; and $86.70 \pm 0.21$ and $1.74 \pm 0.13$, respectively during popping, pressure cooking and germination. The decrease in phytic acid content during popping might have been due to the reason that they are heat labile and thus lost during popping. The decrease in phytic acid content during pressure cooking and germination can be attributed to leaching of phytate ions into water under the influence of concentration gradient and also due to hydrolytic activity of phytase reported to be present in many plant foods. It is clear from table that untreated koda samples contained $5.67 \pm 0.31 \mathrm{mg} / 100 \mathrm{~g}$ saponin which decreased to $5.53 \pm 0.24 \mathrm{mg} / 100 \mathrm{~g}$ during popping, $4.76 \pm$ $0.58 \mathrm{mg} / 100 \mathrm{~g}$ during cooking and $5.36 \pm 0.04$ $\mathrm{mg} / 100 \mathrm{~g}$ when germination was done. The reduction in saponin content during popping might have been due to thermal sensitivity. The loss of saponin during pressure cooking and germination might have been due to leaching of these organic compounds in water and enzymatic degradation. Saharan et al., (2002) found decrease in saponin content of fababean and ricebean during germination.

From the present study it can be concluded that koda grain is a rich source of proteins, phytochemicals and dietary fibre constituents and thus, can serve an important role in the diet due to their various health improving benefits. Processing techniques like popping, pressure cooking and germination improved the nutritional quality of koda. In the present study, the followed processing methods significantly decreased antinutritional factors such as saponins $(5.67-4.76 \mathrm{~g} / 100 \mathrm{~g})$, phytic acid $(89.65-84.44 \mathrm{mg} / 100 \mathrm{~g})$ and oxalates $(1.80$ -
$0.51 \mathrm{mg} / 100 \mathrm{~g}$ ), demonstrating that these are the simple, economical and safe approaches for the detoxification of koda grains. Therefore, processed koda flour could be utilized for developing high quality value added products. Nowadays millets are considered as forgotten foods. Koda is one of such millets. Development of value added products from the koda can enhance its post-harvest utilization at household level as well as commercial products.

\section{Acknowledgements}

We thank the "CSK Himachal Pradesh Agriculture University" Palampur, Himachal Pradesh (India) for funding this project.

\section{References}

AOAC. 2010. Official methods of analysis. Association of Official Analytical Chemist, Washigton D.C.UK.14.068, 2057

O'shea, JO., and Maguire, MP. 1962. Determination of calorific value of food stuff by chromic acid oxidation Journal of the Science of Food and Agriculture, 13, 530-532

Makkar, HPS., Blummel, M., Borowy, NK., Becker, K. 1993. Gravimetric determination of tannins and their correlation with chemical and protein precipitating method. Journal of the Science of Food and Agricultur, 61, 161165

Haugh, W., and Lantzch, HJ. 1983. Sensitive method for the rapid determination of phytates in cereals and cereal products. Journal of the Science of Food and Agriculture, 34, 1423-1427

Day, RA., and Underwood, AL. 1986. Qualitative Analysis.5th Ed. New Delhi, India: Prentice Hall Publications. p 701

Obadoni, BO., Ochuko, PO. 2001. Phytochemical studies and comparative efficacy of the crude extracts of some homeostatic plants in Edo and Delta States of Nigeria. Global Journal of Pure and Applied Science 8, 203-208 
Sheoran, OP., Tonk, DS., Kaushik, LS., Hasija, RC., and Pannu, RS. 1998 Statistical Software Package for Agricultural Research Workers. Recent Advances in information theory, Statistics \& Computer Applications by D.S. Hooda \& R.C. Hasija Department of Mathematics Statistics, CCS HAU, Hisar, 1988, pp. 139-143

Nazni, P., and Bhuvaneswari, J. 2015. Analysis of physico chemical and functional characteristics of finger millet (Eleusine coracana L.) and little millet ( $P$. Sumantranse). International journal of food and nutritional sciences 4(3): 109 144

Malik, M., Singh, U., and Dhaiya, S. 2002. Nutrient composition of pearl millet as influence by genotypes and cooking method. Journal of Food Science and Technology, 39(5), 463-468

Modgil, R., Joshi, R., and Tanwar, B. 2016. Effect of domestic processing on physico chemical and nutritional quality of fenugreek cultivars Asian Journal of Dairy \& Food Research, 35 (4), 338-340

Akubor, PI., and Obiegbunna, JE. 1999. Certain chemical and functional properties of ungerminated and germinated millet flour. Journal of Food Science and Technology, 36 (3), 241-243.

Thippeswamy, TG., Junna, L., Shinde, M. 2016. Proximate composition, resistant starch and other phytochemical constituents of native finger millet cultivar. International Journal of Food and Nutrition Science, 5(3), 67 79

Katake, SB., Kachare, DP., and Naik, RM. 2016. Evaluation of finger millet genotypes for proximate composition and antinutrients content. International Journal of Science, Environment, 5(5), 3596 - 3602
Akintosotu, A., and Akinyele, IO. 1991. The effect of germination on the oligosaccharide and nutrient content of cowpea, Food Chemistry, 39(2), 157-165.

Dharmaraj, U., and Malleshi, NG. 2011 Changes in carbohydrates, proteins and lipids of finger millet after hydrothermal processing. Food Science and Technology 44: $1636-1642$

Saharan, K., Khetarpaul, N., and Bishnoi, S. 2002. Antinutrients and protein digertibility of faba beans and rice beans as affected by soaking, dehulling and germination. Journal of Food Science and Technology 39: 418 - 422

FAO. 2012. Grassland Index. A searchable catalogue of grass and forage legumes. Food and Agriculture Organization of the United Nations, Rome, Italy

FAO. 2017. The state of food security and nutrition in the world. Building resilience for peace and food security. Food and Agriculture Organization of the United Nations, Rome

Adebowale, YA., Adeyemi, IA., and Oshodi, AA. 2005. Functional and physicochemical properties of six mucun species. African journal of biotechnology, 4, 416-468

Schoch, TJ. 1964. Swelling power and solubility of granular starches. Methods in Carbohydrate Chemistry, 4, $106-108$

Van Soest, PJ., and Wine, RH. 1967. Use of detergent in the analysis of fibrous foods, determination of plant cell wall constituents. Journal of Association of Official Analytical Chemistry, 50, 50

Van Soest, PJ., and Robertson, JB. 1985. Analysis of Forages and Fibrous Foods, laboratory manual for animal science. Cornell University Press, (p 202).

\section{How to cite this article:}

Shalini Devi and Rajni Modgil 2020. Physico-chemical Characteristics, Functional Properties and Antinutritional Factors of Domestically Processed Sub Himalayan Non- conventional Millet koda (Eleusine coracana). Int.J.Curr.Microbiol.App.Sci. 9(11): 2808-2817. doi: https://doi.org/10.20546/ijcmas.2020.911.340 